\title{
Rainwater Harvesting Potentialities to Reduce Over Extraction of Groundwater in Sylhet
}

\author{
Munna, G. $\mathbf{M}^{1^{*}}$, Alam J. B ${ }^{1}$, Uddin M. $\mathbf{M}^{1}$, Islam, M. A ${ }^{1}$, Tonmoy, K. T. R ${ }^{2}$, Hridoy, I. A ${ }^{2}$
}

${ }^{1}$ Faculty, Department of Civil \& Environmental Engineering, Shahjalal University of Science \& Technology, Sylhet, Bangladesh

${ }^{2}$ Ex-Student, Department of Civil \& Environmental Engineering, Shahjalal University of Science \& Technology, Sylhet, Bangladesh

DOI: $10.36347 /$ sjet.2020.v08i03.003

| Received: 22.02.2020 | Accepted: 06.03.2020 | Published: 19.03.2020

*Corresponding author: Gulam Md. Munna

Abstract Original Research Article

Water is plainly the single biggest issue confronting the nation today. Water shortage will be one of the significant dangers to mankind during this century. This study intends to reassess the technique by which the water can be collected or stored safely. In this research Sylhet city is considered, where the ground water table is comparatively lower. Therefore, collecting rainwater can be a rational solution to this problem, which is normal in numerous spots in Sylhet especially in the hilly regions on the north eastern piece of the city. This can be an elective wellspring of drinking water due to accessibility of water from March to October. Heavy rain happens from end of May till midSeptember, which is usually known as the rainy season. The capacity of tank is determined and the attainability or feasibility specially for drinking purposes is checked to reduce over extraction on groundwater. In this study, it is found that the total collected water by rainwater harvesting for four different buildings satisfied the water demand by calculate these catchment. Here for an academic building we get the total water $6830.08 \mathrm{~m}^{3}$ for a catchment area $1679.3 \mathrm{~m}^{2}$ in a year 2017, which required a tank size $8680 \mathrm{~m}^{3}$ which can be served throughout the year and also satisfies $50-60 \%$ of overall demand.

Keywords: Rainwater, Harvest, Catchment, Feasibility, Storage tank.

Copyright @ 2020: This is an open-access article distributed under the terms of the Creative Commons Attribution license which permits unrestricted use, distribution, and reproduction in any medium for non-commercial use (NonCommercial, or CC-BY-NC) provided the original author and source are credited.

\section{INTRODUCTION}

Rainwater harvesting is a generally utilized term covering each one of those systems whereby rain is collected and utilized close to where it first achieves in the earth. The term has been connected to make precipitation permit the ground as opposed to keep running off its surface to types of flood control to the development of little repositories [1]. Rain falls onto rooftops and after that keeps running off. To catch runoff water with the goal that is very well may be utilized for steers or miniaturized scale water system and to the gathering of run-off from rooftops and other impermeable surfaces [2]. Rainwater harvesting can be considered as a plausible arrangement of drinking water emergency in zones where there is no plausibility of giving safe water inexpensively inside a sensible separation of homes on the grounds that the ground conditions are inadmissible and surface waters are dirtied or missing. Rainwater harvesting is utilized to supply water to that very structure with no requirement for the water to be conveyed from some place progressively far off. In the seaside belt and hilly areas of Bangladesh reasonable water sources are scarce. The beach front belt experiences high saltiness in surface and ground water and the sloping zone experience the ill effects of nonattendance of surface and ground water for the advancement of a reliable water supply system. The normal yearly precipitation in the seaside and bumpy locals is more than $3000 \mathrm{~mm}$ against a normal precipitation of around $2400 \mathrm{~mm}$ in Bangladesh. The gathering and capacity of water is a substitute of water supply in these areas. Rainwater harvesting is a potential water supply choice in the intense arsenic influenced regions of Bangladesh. Rainwater accumulation in Bangladesh has been rehearsed for quite a while on a constrained scale. In Bangladesh, surface water was the essential source for drinking water ever up to later past. Be that as it may, amid the ongoing decades, because of the serious advancement programs, the ground water is used for savoring reason in most rustic regions. Shockingly, ongoing investigations have demonstrated almost countrywide event of high arsenic levels in the tube well water. Today, Bangladesh seems to be a standout amongst the most arsenic influenced nations on the planet, Bangladesh is a tropical nation and gets overwhelming precipitation amid the rainy season. In the present 
situation, water collecting is in effect genuinely considered as an elective alternative for water supply in Bangladesh. Ninety seven percent of rustic populace approaches tube well water and ground water is still good for all type of uses except drinking. In the beach front belt, high saltiness in surface and ground water and in the sloping zones, nonattendance of good ground water aquifers just as challenges in tube well development in stony layers are the principle requirements for the advancement of a reliable water supply framework. Arrangement of arsenic sullying free water is critically needed to moderate arsenic poisonous quality and to ensure the wellbeing and prosperity of the country populace living in intense arsenic affected zones. The general population, especially the ladies, living in the arsenic affected regions need to walk long distance to bring water from an accessible source.
Bangladesh is a tropical nation and gets overwhelming precipitation amid the rainy season. In the seaside regions, especially in the seaward islands of Bangladesh, water collecting for drinking object is a typical practice on a restricted scale for quite a while. In some regions having a high salinity problem, about 36 percent of the family units have been found to practice rainwater harvesting in the rainy season for drinking reason [3]. The main advantages of a rainwater system are that the quality of rainwater is comparatively good. The accessibility of water is constrained by the precipitation force and accessibility of an appropriate catchment area. The mineral free water may not be liked by many people and the general population might not have a suitable roof or catchment area for rainwater harvesting.

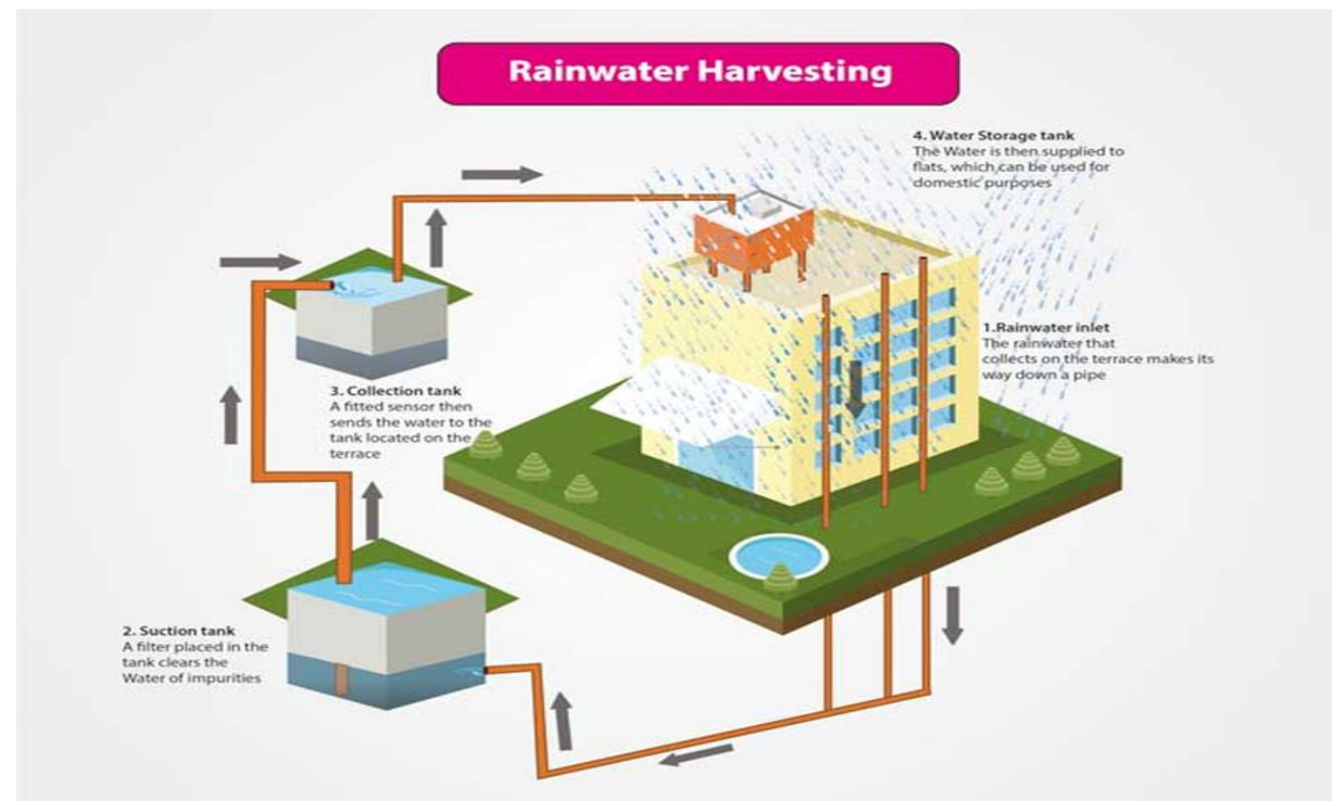

Fig-1: Rainwater harvesting system

\section{RWH potentialities in Bangladesh}

Water is gathered as it keeps running from rooftops, or as surface overflow streaming on regular ground, streets, yards, or specially prepared ground surface catchments. Rock catchment frameworks can likewise be conceivable where enjoined shake outcrops give appropriate catchment surfaces. The spillover is diverted along stone and bond drains built on the stone surface into stores contained by solid dams. Depending on conditions, water is gathered from roofs or while running over ground surfaces. As the water gathered from rooftops is normally very perfect, this water is best utilized for drinking and cooking purposes. Extra water required for washing and watering a vegetable greenhouse can be taken from less spotless sources, for example, underground tank gathering surface overflow [4]. The housetop water harvesting framework appears to be appropriate for Bangladesh, as the framework will be structured distinctly to supply drinking and cooking water. "In this examination, an endeavor was made to ascertain the required stockpiling volume for water harvesting framework. This country has mostly plain land mass with some tough regions on the upper east and east and a beach front range toward the south and southeast with seashores and estuaries. Absence of sufficient safe drinking water is a serious issue in southern beach front and eastern sloping zones. While in beach front regions ground and surface water is salty, wellspring of consumable water is constrained in uneven territories as burrowing wells is troublesome and expensive. Tropical rainstorm conveys high precipitation from April to September $(125$ to $500 \mathrm{~cm})$. The normal yearly recorded precipitation inside Bangladesh shifts from around $110 \mathrm{~cm}$ in the extraordinary west to $569 \mathrm{~cm}$ in the northeastern corner of the nation. Consistently, yearly precipitation ranges from $143.5 \mathrm{~cm}$ in Rajshahi to $417.71 \mathrm{~cm}$ in Sylhet, around $500 \mathrm{~cm}$ in Cox's bazaar to around $533 \mathrm{~cm}$ in Sunamganj. In Bangladesh, yearly precipitation is least in the focal west: $125 \mathrm{~cm}$, which increments towards the 
north, east and south achieving in excess of $250 \mathrm{~cm}$ in the outrageous northwest (at Panchagar) and in the northern and eastern slopes and close to the coast; it surpasses $500 \mathrm{~cm}$ in the extraordinary north east [5]. Because of the accessibility of a tremendous measure of water, spontaneous water harvesting has been practically speaking in Bangladesh since long. Despite the fact that individuals living in beach front and uneven zones of Bangladesh have a background marked by gathering and utilizing water, no particular investigation on water accumulation and its utilization has been finished. In line of surveying the possibility of water harvesting and assessing distinctive accessible water collecting methods, Civil and Environmental Engineering branch of SUST led a contextual analysis on water collecting system in KANISHAIL during 2003-04 build-up the first pilot plant in Sylhet City [6]. The reason for the contextual analysis was to build up a possible water collecting strategy and screen the quality of harvested water. Water collecting strategies in the past produced for unimportant presence are these days accepting reestablished consideration since they can add to expanded water supplies for drinking and household use. To provide drinking water for individuals, domesticated animals, and wild life, water collecting framework can give supplemental water to developing sustenance and fiber crops.

\section{Components of Rainwater Harvesting The Roof}

To be 'reasonable' the rooftop ought to be made of some hard material that does not retain the rainwater or contaminate the run-off. Subsequently, tiles, metal sheets and most plastics are appropriate, while grass and palm-leaf rooftops are commonly not appropriate. The bigger the rooftop, the greater the runoff stream. The water achieving a rooftop in a year can be evaluated as the yearly precipitation times the rooftop's arrangement zone, yet in the tropics just about $85 \%$ of this water keeps running off the rooftop. The staying $15 \%$ is normally lost to dissipation and sprinkling.

\section{Guttering}

The course of action for driving water from the rooftop to the water store is generally called 'guttering' or 'drains and downpipes'. The drains are open channels conveying water sideways under the edge of the rooftop to a point simply over the water store; It's driving water down from the roof to the storage tank.

Other components-Some components of rainwater harvesting are given below:
a. Screens
b. Filters
c. overflow arrangements
d. level gauges
e. Pumps etc.

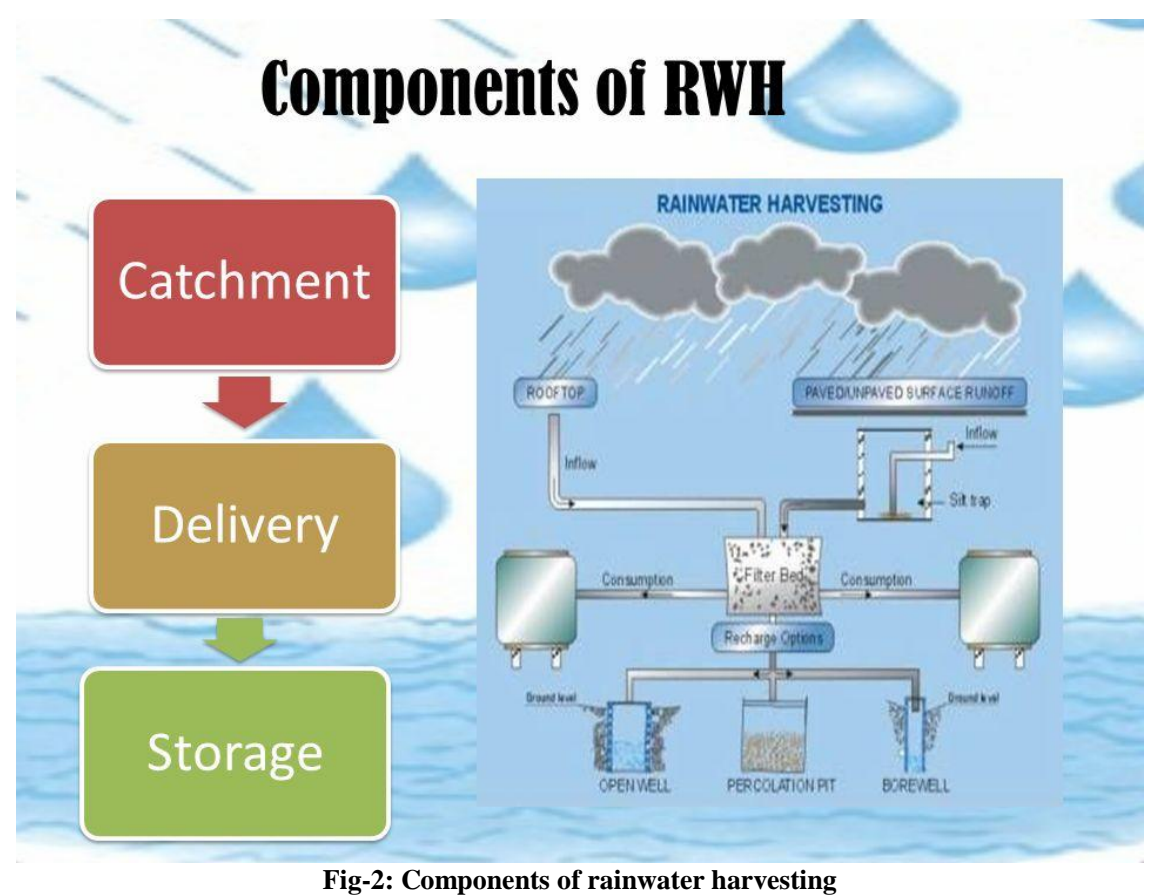

\section{METHOGOLOGY}

The methods evolved during the initial research following the evaluation of literature and new learning concept in quasi-qualitative research and secondary analysis methods. The literature collected enlightened the researcher's understanding of practical and effective methods for researching educational phenomena in a technical life. New concepts in quasiqualitative and interpretative approaches enabled the researcher's adaptation of appropriate methods for the unique focus of this study. 


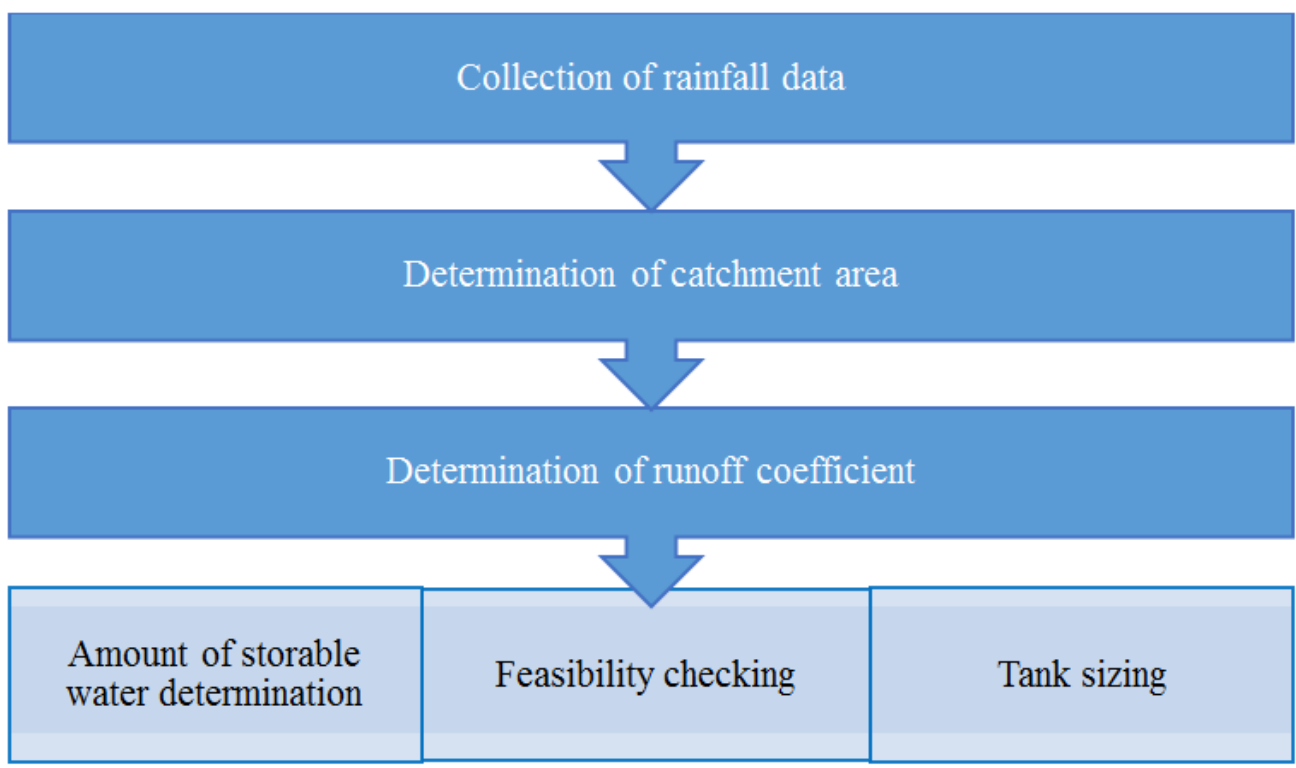

Fig-3: Flow Chart of the Methodology

\section{Study Area}

The study area is Sylhet, one of the most densely populated city of our country. Four buildings has been selected for this research work in Sylhet. The zone is inside the rainstorm climatic zone that outcomes an overwhelming precipitation in storm. Sylhet is found very close to Cherapunji, which gets the most astounding precipitation in the world. So, heavy rainfall occurs in Sylhet every year.

\section{Collection of Rainfall Data}

The observed daily and monthly rainfall data of 30 selected rain gauge stations of Bangladesh during the period 2008-2018 (11 years) were collected from the Climate Division of Bangladesh Meteorological Department (BMD) [7]. The stations are selected on the basis of uniform spatial distribution and availability of maximum data length and data accuracy. From the meteorological point of view, there are four climatic seasons in Bangladesh. They are: Winter (DecemberFebruary), Pre-monsoon (March-May), Monsoon (June-September) and Post monsoon (OctoberNovember). This classification of seasons, as mentioned above, has been considered in many reports of SMRC and BMD [8]. Throughout this study, the term winter and monsoon simply means northeast winter monsoon and southwest summer monsoon respectively. The term all-Bangladesh(also referred as country average) rainfall means the average rainfall of all the selected stations of Bangladesh [9]. The monthly, seasonal and annual rainfall data are constructed on the basis of the daily rainfall data. Bangladesh is situated at the interface of two different environments, with the Bay of Bengal to the South and Himalayas to the north. Due to its geographical position, Bangladesh experiences highest amount of country average monsoon and annual rainfall among SAARC countries [10].

\section{Determination of Catchment Area}

A catchment is extent of exposed surface area on which precipitation falls and flows towards a draining point. The volume and rate of rainwater runoff are functions of catchment area, intensity and duration of rainfall, slope of surface and type of surface material. Roofs are considered as the first and most effective choice for catchments. Rain falls onto roofs and then runs off. The run-off is extremely variable - for the typically $99 \%$ of each year that it is not raining, run-off flow is zero. However if the run-off is channeled into a tank or jar, water can be drawn from that store whenever it is needed, hours, days or even months after the last rainfall. To be 'suitable' the roof should be made of some hard material that does not absorb the rain or pollute the run-off. Thus, tiles, metal sheets and most plastics are suitable, while grass and palm-leaf roofs are generally not suitable. The larger the roof, the bigger the run-off flow. The rainwater reaching a roof in a year can be estimated as the annual rainfall times the roof's plan area, but in the tropics only about $85 \%$ of this water runs off the roof. In our research we used four selected buildings. We have also used the roof as the catchment area. Catchment area was measured both manually and using the plan of those buildings.

\section{Runoff Co-Efficient}

The roof runoff coefficient $(\mathrm{C})$ is the ratio between the amount of rainwater received from a rain event and the actual rainwater delivered via the gutters and downpipes. The value of this coefficient varies significantly based on roof material, slope of roof etc. This parameter varies in between .75 to .85 . For general purpose 0.8 is used as the value of the coefficient. This coefficient varies with different types of surface [11]. In our research work we have also used 0.8 as the value of runoff coefficient $(\mathrm{C})$. 


\section{Quantity of Storable Water}

The size of the supply of rainwater depends on the amount of rainfall, the area of the catchment, and its runoff coefficient. Rainfall is the most unpredictable variable in the calculation since in many areas, there is considerable variation from one year to the next. An estimate of the approximate mean annual runoff from a given catchment can be obtained using the following equation:

$$
\mathrm{Q}=\mathrm{A} \times \mathrm{R} \times \mathrm{C}
$$

Where,

$\mathrm{Q}=\mathrm{Quantity}$ of total storable water.

$\mathrm{A}=$ Area of catchment area.

$\mathrm{C}=$ Runoff coefficient.

\section{Tank Sizing}

The capacity of the storage tank is very important determinant. It will dictate how much water may be conserved, how much will be the installation cost, how much water will be retained.

The tank must be large enough to ensure that-

- The required volume of water can be collected by the tank.

- The volume of water in the tank is sufficient to meet the demand during the drier months or through periods of low or no rainfall.

- In general, it is found that storage capacity cannot be standardized, being markedly influenced by site-specific variables such as local rainfall, roof area, potable water demand and number of people in the household [6]. There are some common methodologies to determine the size of tank. Such as:

- Dry season demand vs supply
- Simple water budget

- Computer based simulation methods

- Ac-Vc relationship [7]

Among this several methods this study selected "dry season demand vs supply" method.

\section{Dry season demand vs supply method}

This method is generally well suited for arid climates, which have a distinct dry season [12]. In this case, the water demand during the dry season is estimated and the cistern is sized to store enough water to sustain the dry season.

According to this method-

$$
\mathrm{V}=\mathrm{n} \times \mathrm{d} \times \mathrm{q}
$$

Where,

$$
\begin{aligned}
& \mathrm{V}=\text { Volume of the storage tank. } \\
& \mathrm{n}=\text { Number of water users. } \\
& \mathrm{d}=\text { Number of dry days. } \\
& \mathrm{q}=\text { Per capita demand. }
\end{aligned}
$$

For the rest three buildings same procedure is used.

\section{Feasibility Checking}

The feasibility or reliability of rainwater harvesting system is defined as the probability that the capacity of the system equals or exceeds the demand [13]. So feasibility or reliability of the system depends mostly on satisfaction of the demand. In our research demand satisfaction is calculated by the total demand of the building with respect of its maximum available water which is stored in the storage tank. Finally the relationship is presented in graph.

\section{RESULT AND DISCUSSION}

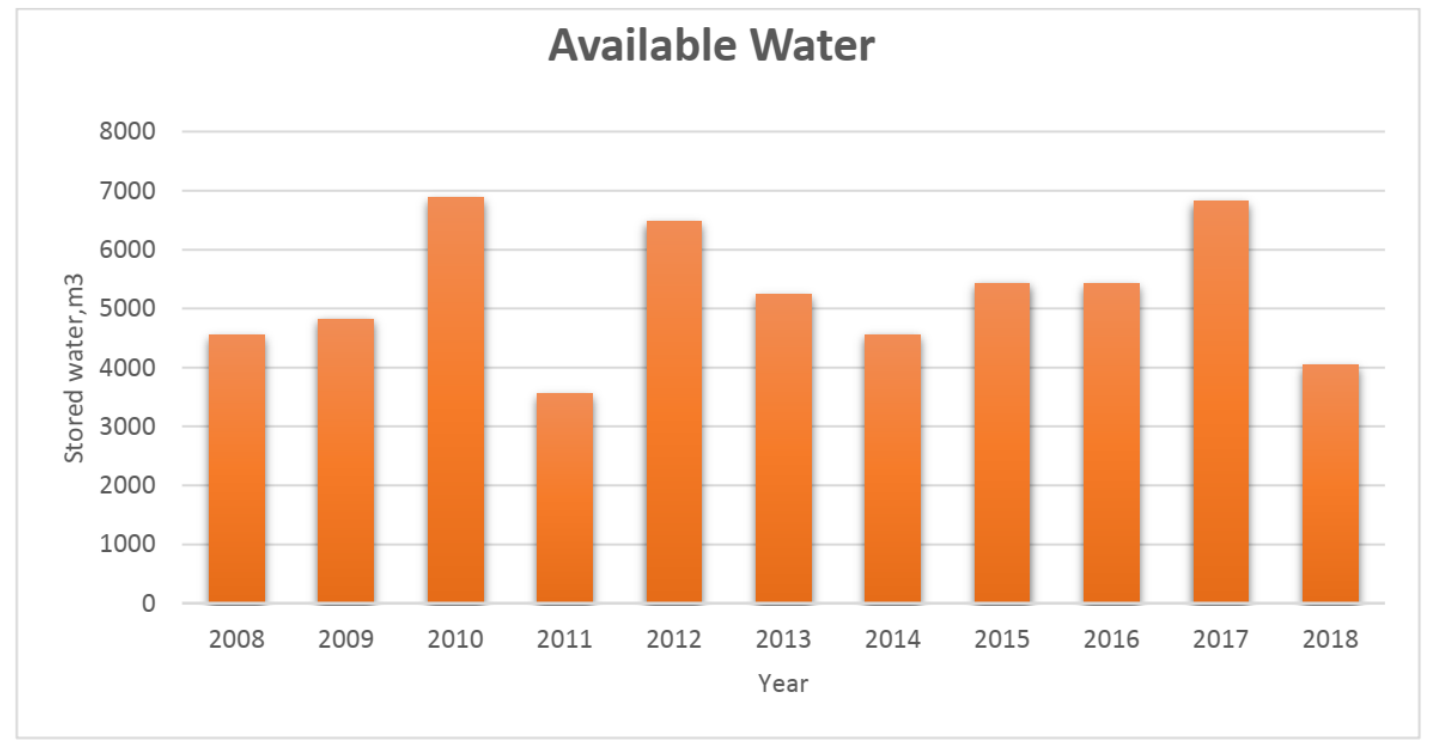

Fig-4: Available rain water of last ten years from "academic building C" 


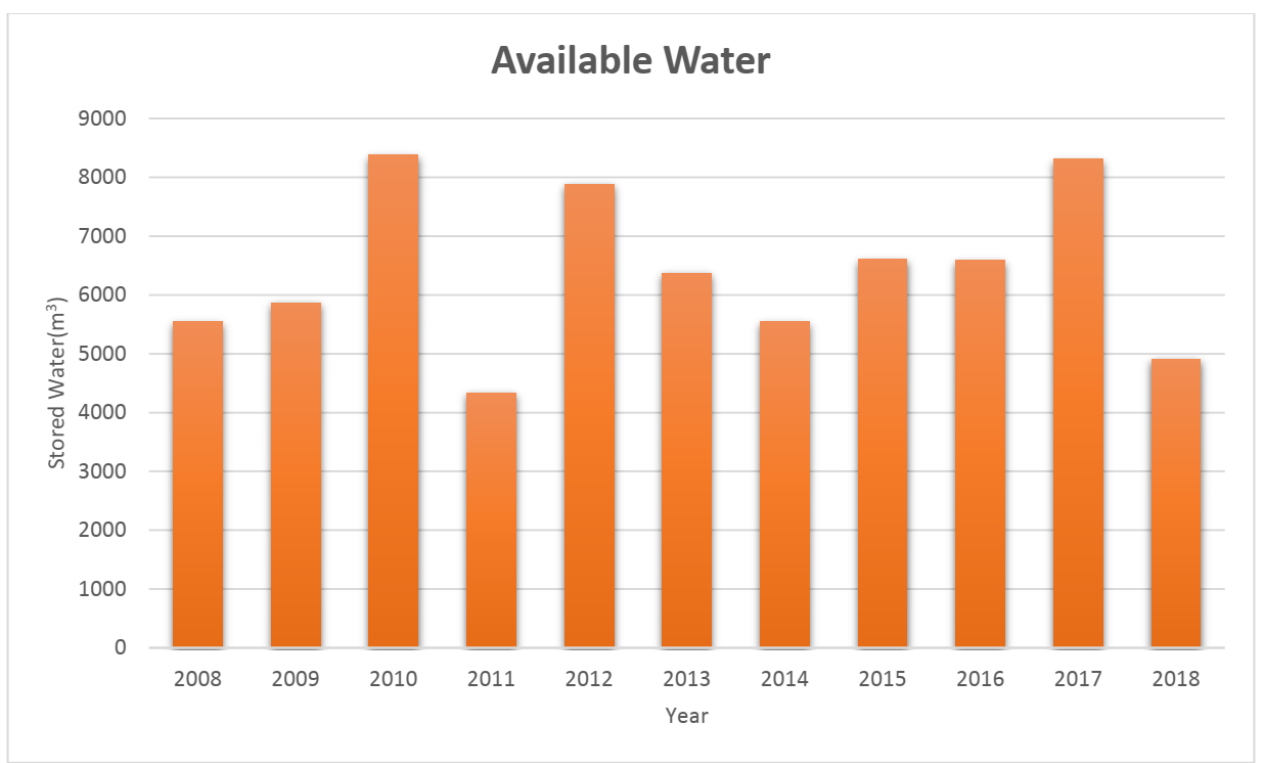

Fig-5: Available rain water of last ten years from Shahporan Hall (SUST)

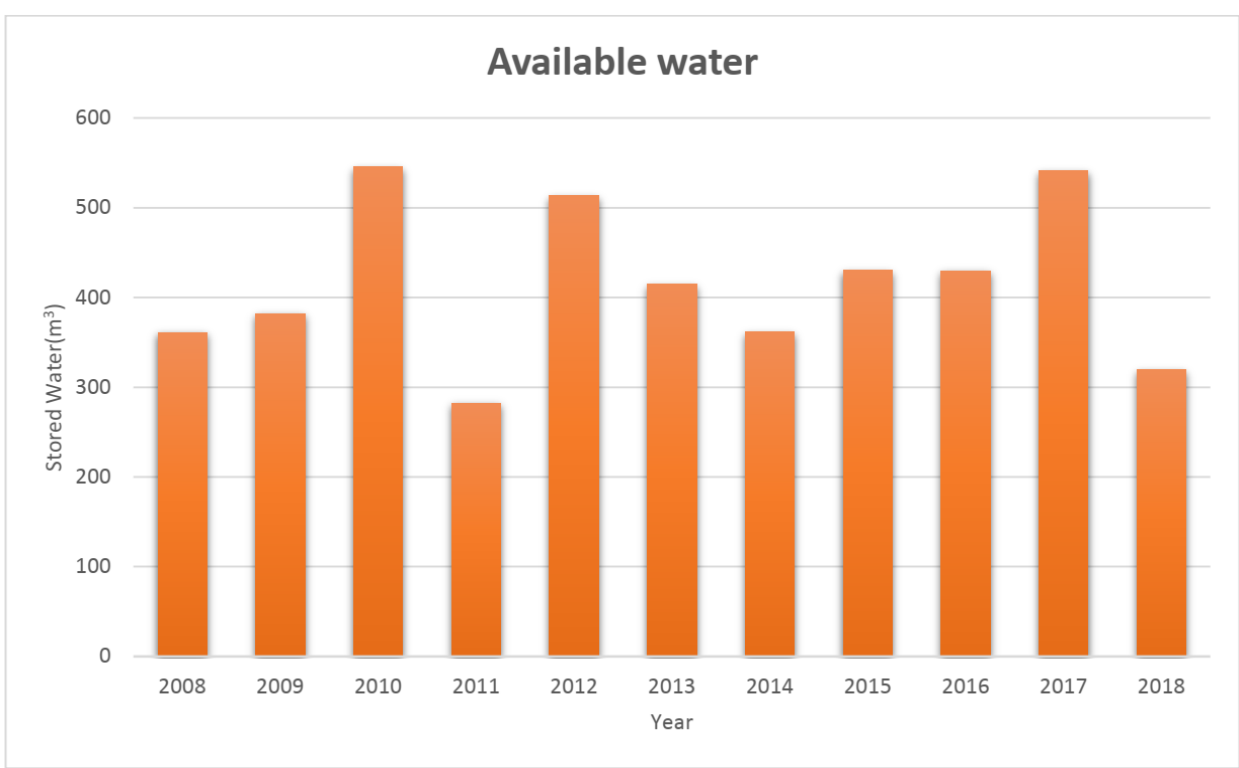

Fig-6: Available rain water of last ten years from "Residential Building (Surma)

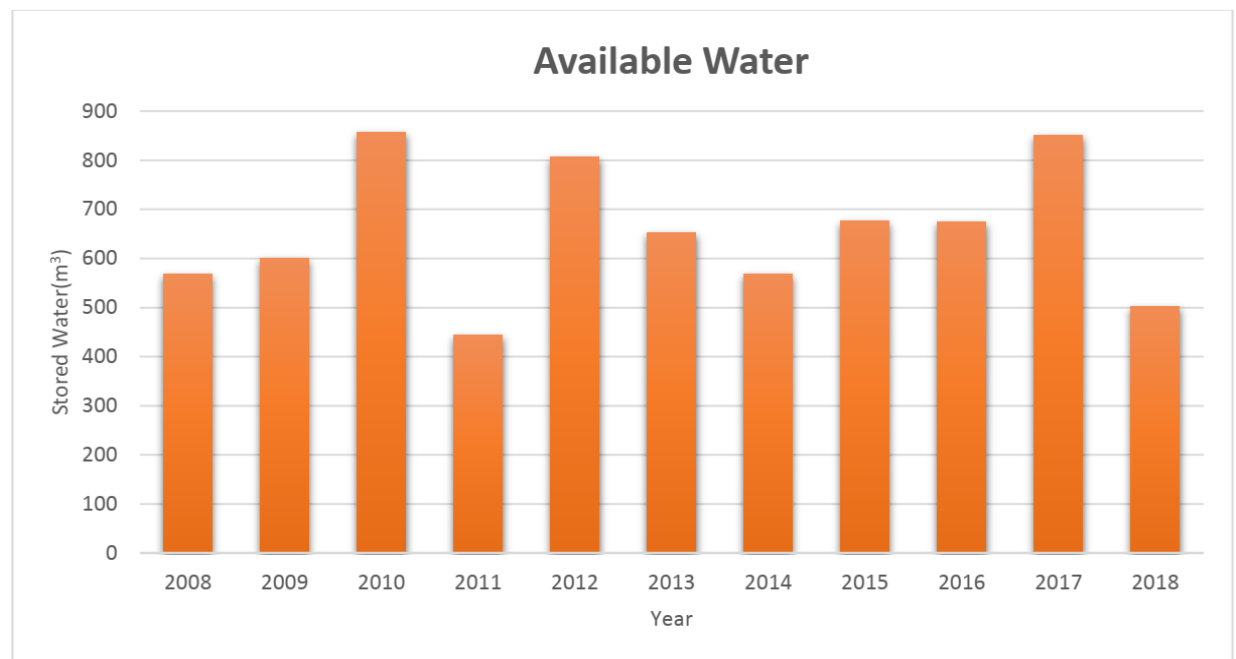

Fig-7: Available rain water of last ten years from "Student Hostel (Topobon) 


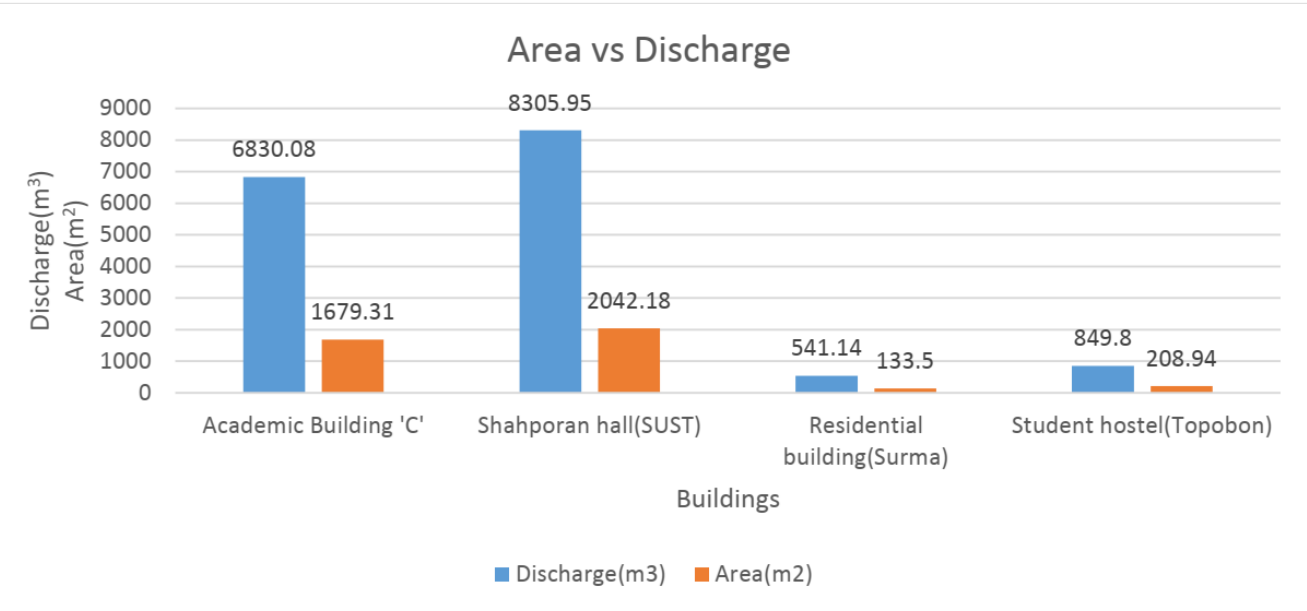

Fig-8: Area and Discharge comparison

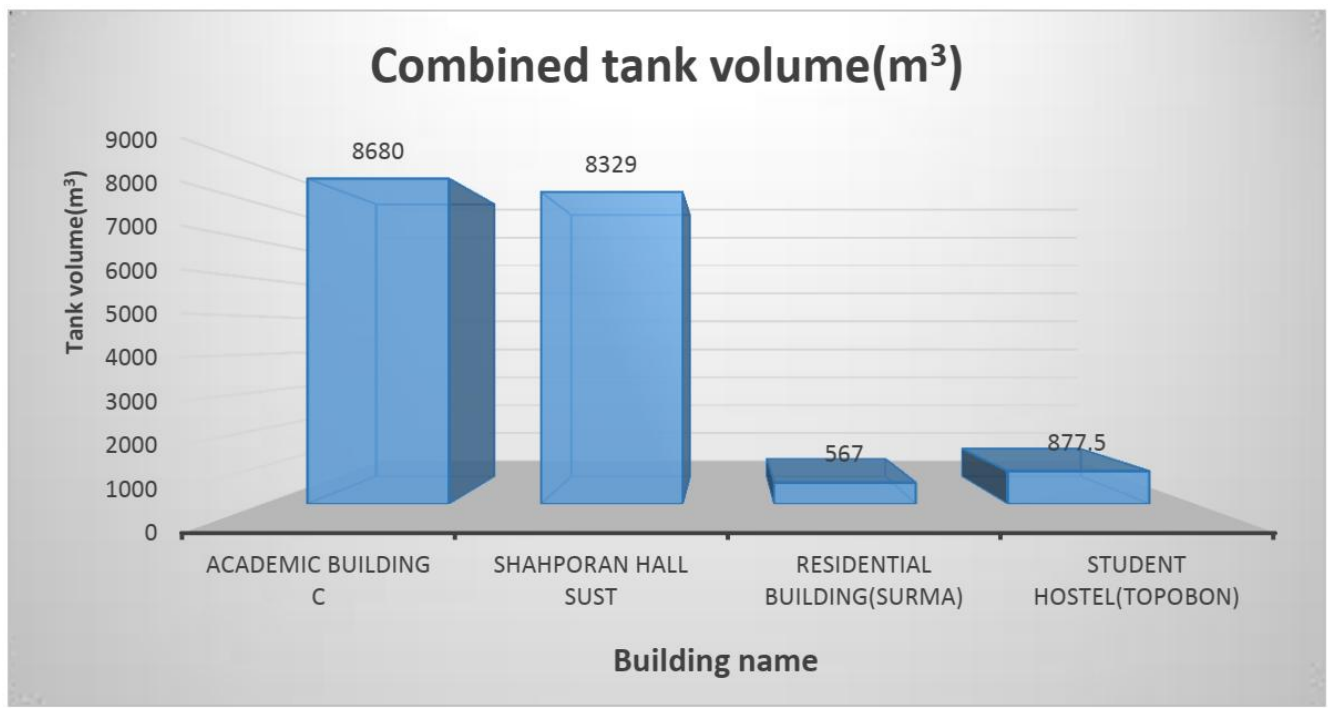

Fig-9: Size of tank for selected four buildings

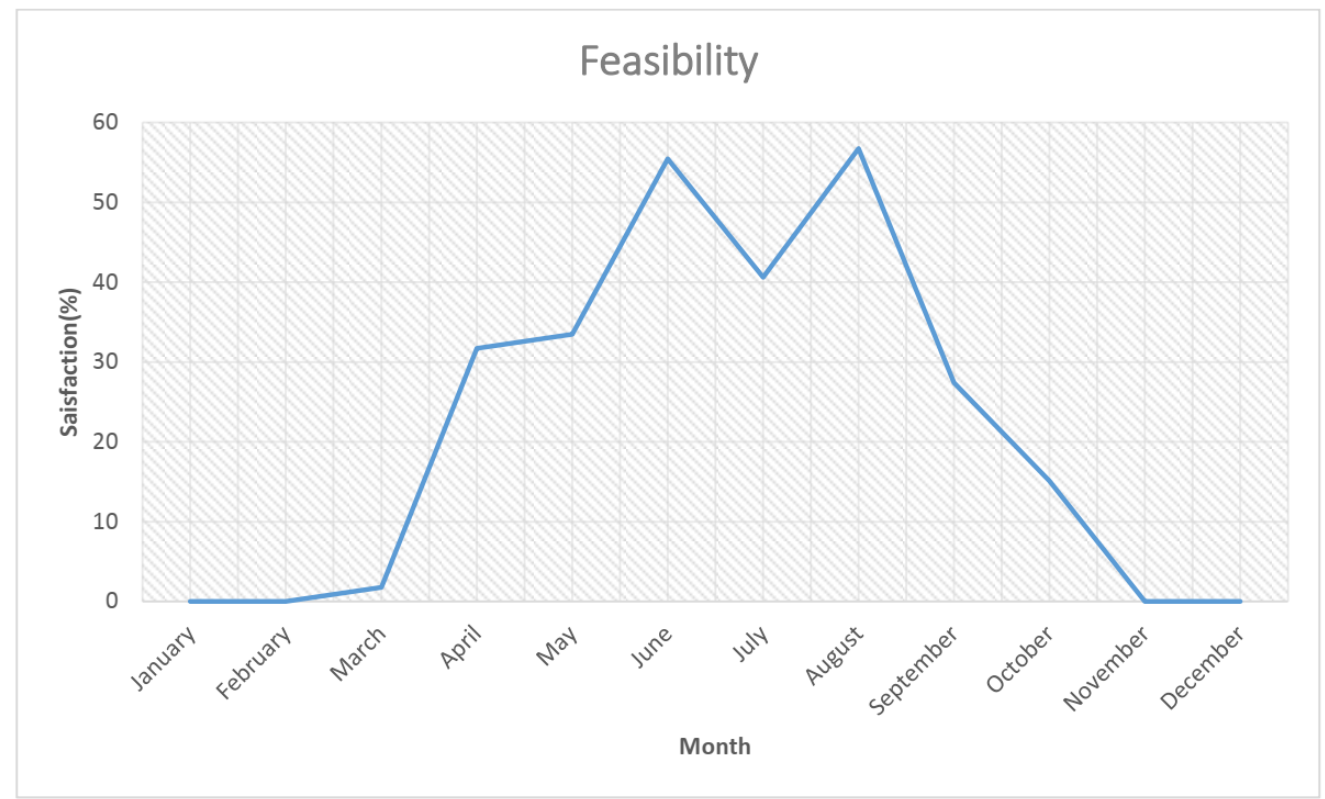

Fig-10: Monthly satisfaction (\%) in 2017 for Academic building C 


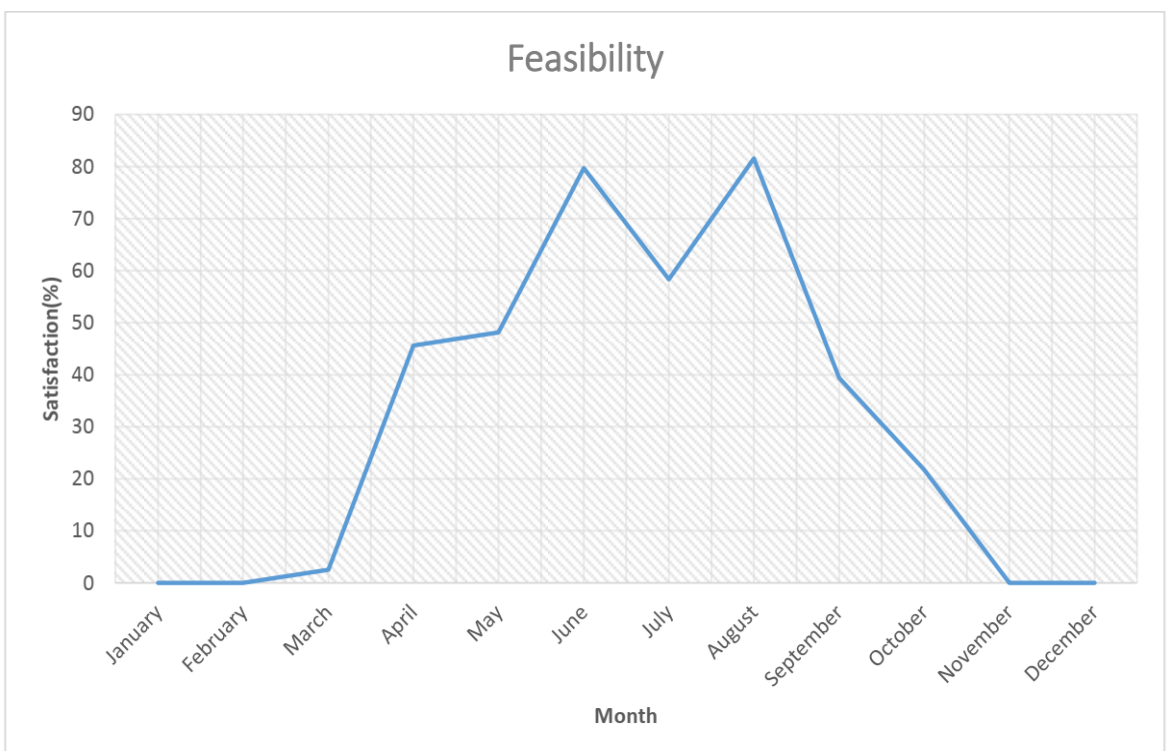

Fig-11: Monthly satisfaction (\%) in 2017 for Shahporan Hall (SUST)

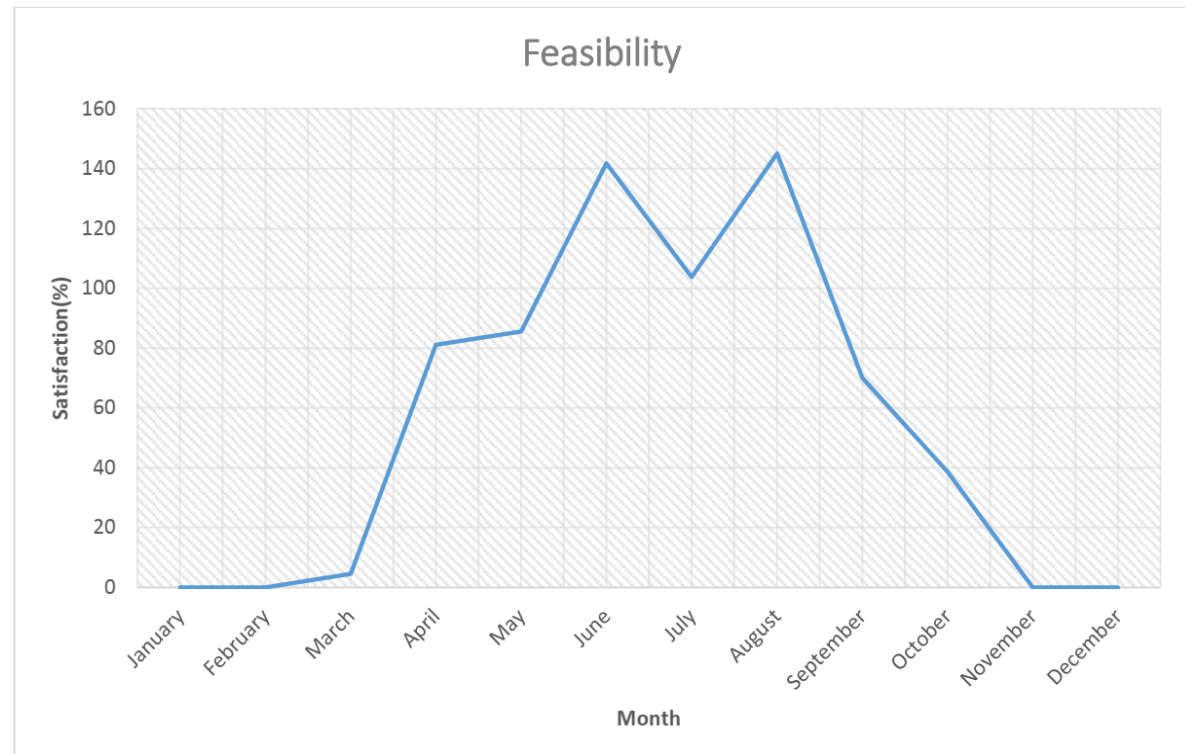

Fig-12: Monthly satisfaction (\%) in 2017 for Residential Building (Surma)

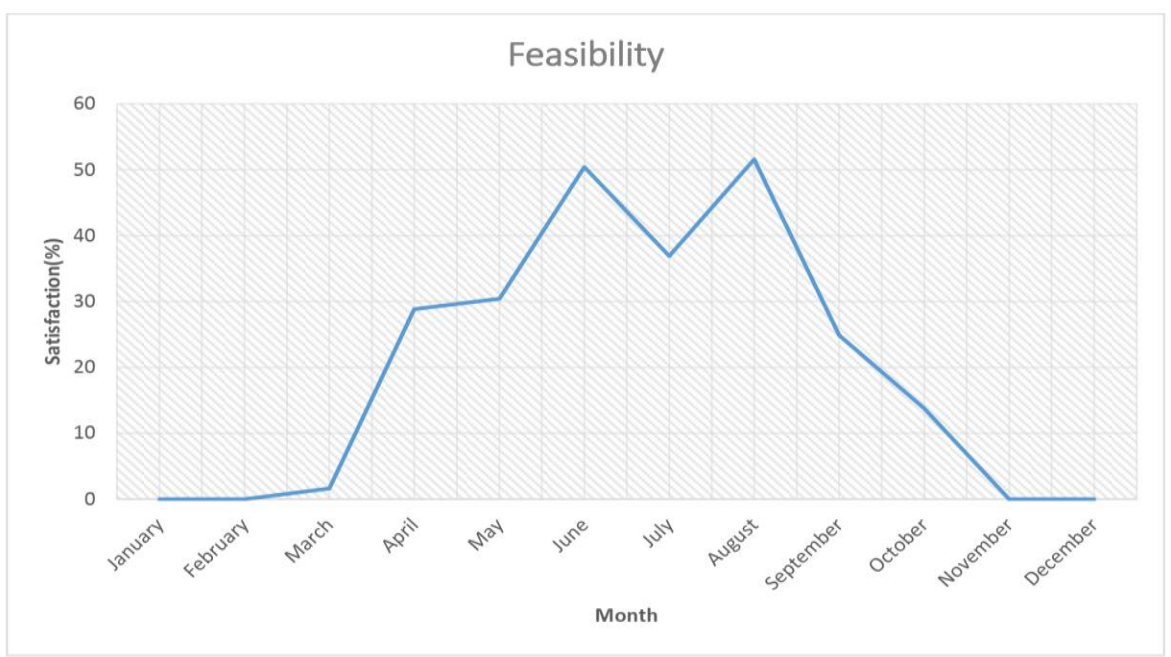

Fig-13: Monthly satisfaction (\%) in 2017 for Student Hostel (Topobon) 


\section{Feasibility checking according to season}

Bangladesh is called the land of six seasons. It has a temperate climate because of its physical location. Though the climate of Bangladesh is mainly subtropical monsoon. Bangla calendar year is traditionally divided into six seasons: summer, Rainy, autumn, late autumn, winter and spring. Each season comprises two months, but some seasons flow into other seasons, while others are short. Actually, Bangladesh has three distinct seasons: the pre-monsoon hot season from March through May, rainy monsoon season which lasts from June through October, and a cool dry winter season from November through February [14].

Dry season: Satisfaction (\%) is shown below for dry season for our selected four buildings-

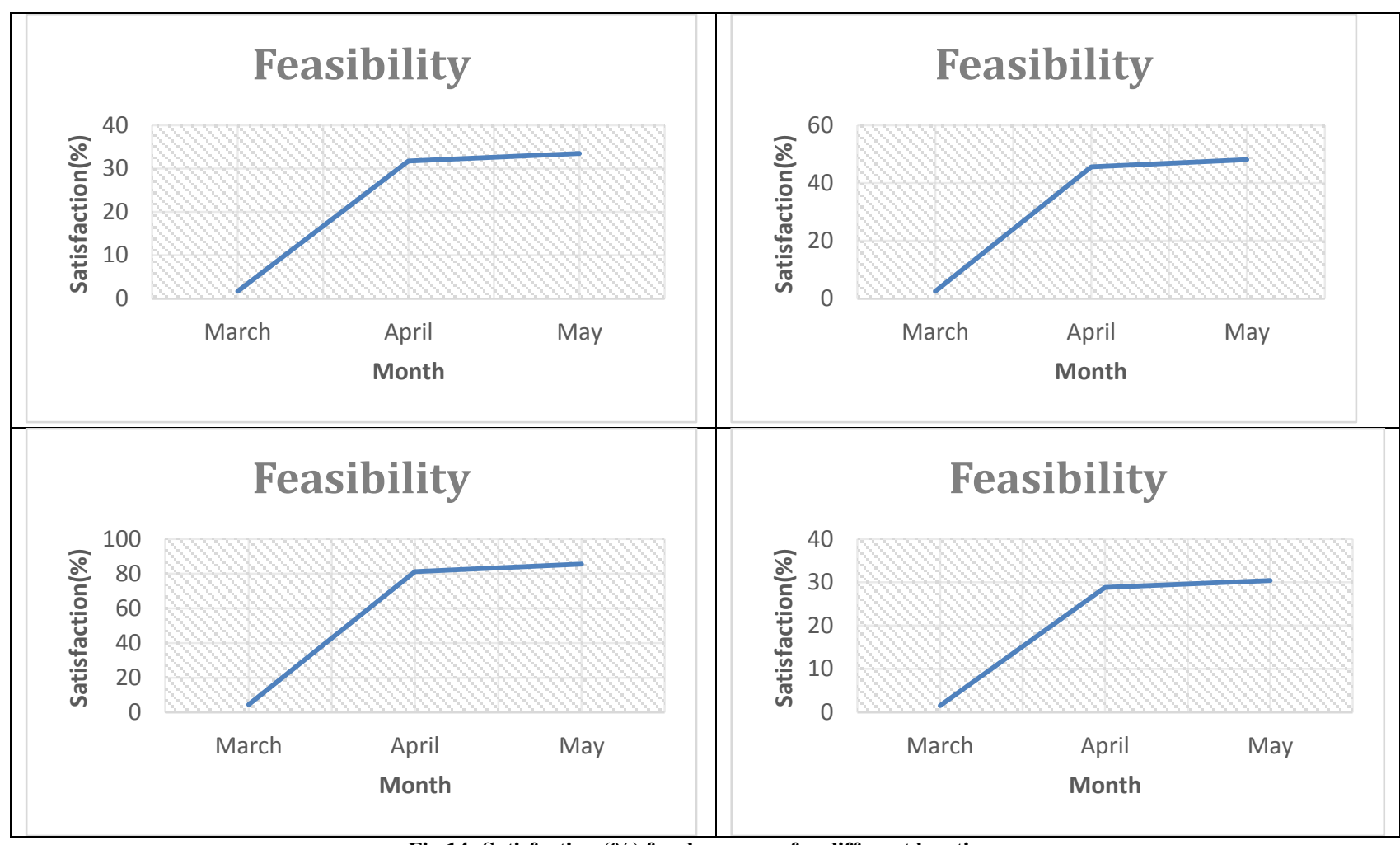

Fig 14: Satisfaction (\%) for dry season for different locations

Rainy Season: Satisfaction (\%) is shown below for rainy season for our selected four buildings-

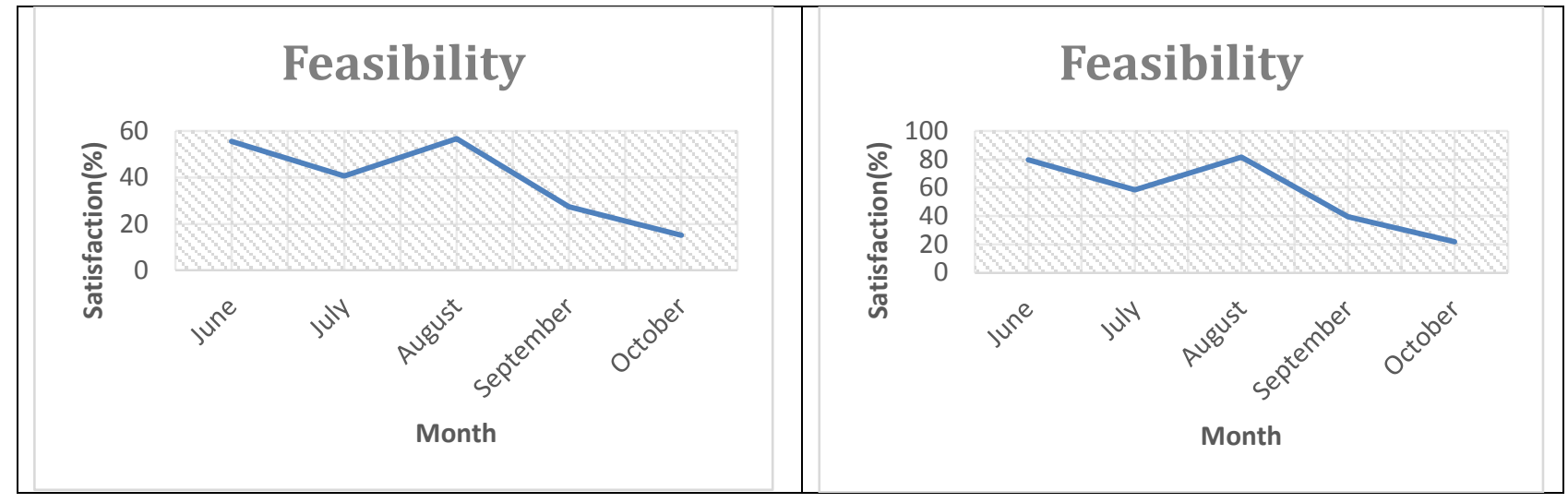




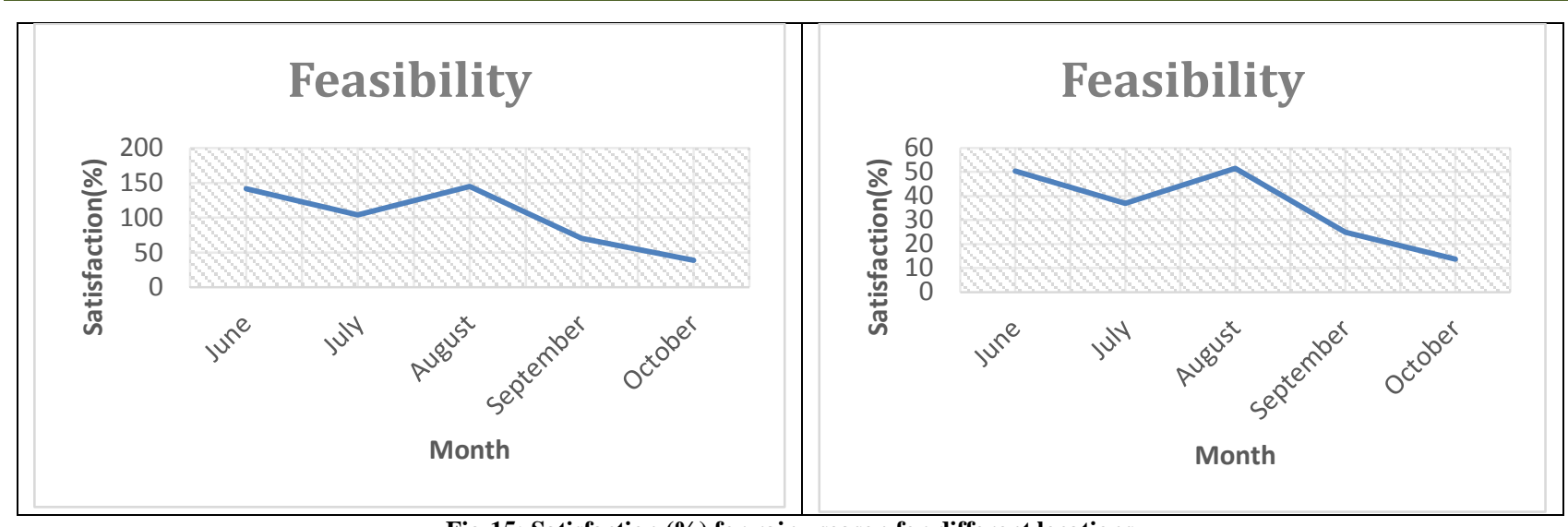

Fig-15: Satisfaction (\%) for rainy season for different locations

Winter season: As no rainfall occurs in rainy season so the system is not feasible for that specific season.

\section{CONCLUSION}

Result shows that we can collect huge amount of water by rainwater harvesting every year. Depending upon the catchment area the amount of collected water is changed. If we can store this huge amount of water it must reduce the over extraction of groundwater. We can store huge amount of water from the roof or catchment area of building but to run the rain water harvesting system feasibility must be checked. From feasibility graph we can see in June, July, august we need not use any ground water, more over we can store for the dry season. From result we can see for residential building the rain water harvesting system is more feasible. As number of users of a residential building is less than academic building or hall its water demand is also less. In the case of residential building rainwater can satisfy the whole demand of users during rainy season and extra water can be stored for dry season. From results, it is observed that during rainy seasons (Jun-Jul) due to heavy rainfall by harvesting rainwater maximum percentage of demand satisfaction can be gained. Though the system cannot serve well in other seasons but as it will be beneficial to the inhabitants during rainy season to cope with the existing water crisis it can be a very good alternative to have. It served exceptionally well for the two storied single residential building as they had comparatively large catchment area with respect of number of inhabitants of building than others. But according to the analysis rainwater harvesting system can only serve well in the month June, July, August. For the rest of the months still Sylhet has to be dependent on groundwater. But, over extraction of groundwater resulting in depletion of ground water table. This has become so severe that in some areas deep tube wells going down over $300 \mathrm{ft}$ under the ground are unable to extract water. In the arsenic contaminated areas, this source might be an alternate option of water source. Also in the scarce safe drinking water areas like Dhaka, it might be very useful. The water quality is acceptable as safe drinking water in Dhaka areas up to four months and it is applicable only for this area, because the other cities, the air quality might not be the same, so the rainwater quality might differ. Tank size is a salient feature in regards to maximization of rainwater harvesting and determination of optimum tank size is a complex function dependent on annual rainfall amount, catchment area and demand. Although, existing underground tanks were not intended for the purpose of rainwater harvesting, the results indicated that these tanks with current sizes in these cities are sufficient to prevent the spillage of harvested rainwater, although an insignificant amount of water spillage is expected for the RWH system in Sylhet. Overall, the reliabilities of rainwater harvesting systems with different water demands and tank sizes under various climatic conditions vary widely for these cities. The temporal variability of rainfall is one of the most important factors in designing a rainwater harvesting system. Although the efficiency found is not much greater as compared to the present water demand, water supply authorities of Bangladesh should consider the potentials of rainwater harvesting to partially offset the water demand in these cities. Installation of RWH systems in the multistoried residential buildings will not only lead to economic savings and water stress reduction but also go further in reducing the water clogging problem in these cities. Government should take initiatives to educate the urban dwellers on water conservation benefits associated with RWH implementation in urban areas of Bangladesh to achieve a sustainable future.

\section{REFERENCES}

1. Martinson B, Thomas T. Roofwater harvesting: a handbook for practitioners. IRC International Water and Sanitation Centre; 2007.

2. Narain P, Khan MA, Singh G. Potental for water conservation and havesting against drought in Rajasthan. IWMI; 2006 Jan 23.

3. Hussain D, Ziauddin AT. Rainwater use in Bangladesh: A case study in Dacope Upozilla. InProc. 4th International Conference on Rainwater Cistern System, Manila 1989 Aug.

4. Hofkes EH. Small community water supplies; technology of small water supply systems in developing countries. Journal Am Water Resources Assoc, 1984; 20(5):803-804. 
5. Graham CB, Woods RA, McDonnell JJ. Hillslope threshold response to rainfall:(1) A field based forensic approach. Journal of Hydrology. 2010 Oct 27;393(1-2):65-76.

6. Alam R, Munna G, Chowdhury MA, Sarkar MS, Ahmed M, Rahman MT, Jesmin F, Toimoor MA. Feasibility study of rainwater harvesting system in Sylhet City. Environmental monitoring and assessment. 2012 Jan 1;184(1):573-80.

7. Islam M. Rainfall and temperature scenario for Bangladesh. The Open Atmospheric Science Journal. 2009 Apr 30;3(1):93-103.

8. Rafiuddin M, Uyeda H, Islam MN. Characteristics of monsoon precipitation systems in and around Bangladesh. International Journal of Climatology: A Journal of the Royal Meteorological Society. 2010 Jun 15;30(7):104255.

9. Ahasan MN, Chowdhary MA, Quadir DA. Variability and trends of summer monsoon rainfall over Bangladesh. Journal of Hydrology and Meteorology. 2010;7(1):1-7.
10. Devkota S. Distribution and status of highland mushrooms: a study from Dolpa, Nepal. Journal of Natural History Museum. 2008;23:51-9.

11. Zobrist J, Müller SR, Ammann A, Bucheli TD, Mottier V, Ochs M, Schoenenberger R, Eugster J, Boller M. Quality of roof runoff for groundwater infiltration. Water research. $2000 \mathrm{Apr}$ 1;34(5):1455-62.

12. Khan ST, Baksh AA, Papon MT, Ali MA. Rainwater harvesting system: an approach for optimum tank size design and assessment of efficiency. International Journal of Environmental Science and Development. 2017 Jan 1;8(1):37.

13. Ahmed MF. Rainwater harvesting potentials in Bangladesh. 1999.

14. Alamgir M, Shahid S, Hazarika MK, Nashrrullah S, Harun SB, Shamsudin S. Analysis of meteorological drought pattern during different climatic and cropping seasons in Bangladesh. JAWRA Journal of the American Water Resources Association. 2015 Jun;51(3):794-806. 